\title{
ÜÇ BOYUTLU GENOM ORGANIZASYONUNA GENEL BAKIŞ
}

\author{
OVERWIEW OF THREE DIMENSIONAL GENOM ORGANIZATION
}

Evrim Suna ARIKAN'', Müjgan ÖZDEMIR ERDOĞAN', Mustafa SOLAK²

\author{
1Afyonkarahisar Sağlık Bilimleri Üniversitesi, Tıp Fakültesi Tıbbi Biyoloji Anabilim Dalı \\ ${ }^{2}$ Afyonkarahisar Sağlık Bilimleri Üniversitesi, Tıp Fakültesi Tıbbi Genetik Anabilim Dalı
}

\section{öz}

Genomların temel özelliği hücre çekirdeğindeki üç boyutlu topolojik organizasyonudur. "Kromozom alanları" terimi nükleusun belli bölgelerinin belli kromozomlar tarafından kullanılmasını ifade etmektedir. Yani kromozomların nüklear boşlukta rastgele düzenlenmediği, genom içindeki bazı genlerin tercih ettikleri bölgeleri işgal ettikleri tespit edilmiştir. Kromozom alanlarının organizasyonu gen yoğunluğu ve boyutu ile ilişkilidir. Bu durumda gen bakımından zengin kromozomların interior pozisyonları, gen bakımından zayıf kromozomların perifer pozisyonları tercih ettiği rapor edilmiştir. Kromozom alanları ayrıca dinamik yapılardır böylece genler açılacağı zaman periferden interior pozisyona doğru yer değiştirebilirler. Insan genomunun mekansal organizasyonunun genlerin transkripsiyonel kontrolünde önemli bir rol oynadığı bilinmektedir. DNA ilmeklenmesiyle promotör ve enhansır etkileşimleri temelli çalışmalar gen ekspresyonunun uzaktaki kromatin temaslarıyla düzenlendiğini göstermiştir. Düzenleyici DNA elemanları ve genlerin hücreye spesifik transkripsiyon düzenleyici programları nasıl yürüttüğü başta gelen araştırma konularındandır. Genetik çalışmalar enhansır promotör birlikteliğinin üç kuralı etrafında tamamlanır:Doğrusalyakınlıkdurumları,enhansır promotör uyumu ve enhansır aktivitesini bloklayabilen sekansların varlığı. Bu kuralların arkasında yatan moleküler mekanizmaları anlamak için regülatör bölgelerin uzak mesafelerde nasıl faaliyet gösterdiğini bilmeye ihtiyacımız vardır. Herhangi bir hücre tipinin binlerce ya da daha fazla düzenleyici bölge içerdiği bulunmuştur. 200 hücre tipi göz önüne alındığında insan genomunun karmaşık bir düzenleyici sistem olarak çalıştığı görülmektedir. Doğrusal DNA'dan üç boyutlu nükleusa kadar kromatin organizasyonu küçük ve büyük ölçekte çok iyi karakterize edilmiştir ancak ara seviyelerdeki kromatin organizasyonu hakkında bilgilerimiz hala sınırlıdır. Kromozom konformasyonunu yakalama (3C) teknolojilerinin gelişmesi interfaz nükleusunun üç boyutlu kromatin organizasyonuna yeni bakış açısı getirmiştir. $\mathrm{Bu}$ derlemede, genomun mekânsal organizasyonundan, bu organizasyondaki bazı etkileşimlerden ve son yıllarda yapılan bazı çalışmalardan bahsedilmiştir.

ANAHTAR KELIMELER: Üç boyutlu genom, Kromozom alanları, Enhansır, İzolatör, Topolojik domainler

\begin{abstract}
A fundamental property of genomes is their topological organization in the cell nucleus. "Chromosome territories" refer to the use of certain regions of the nucleus by a specific chromosomes. It is determined that, chromosomes are not arranged randomly in the cell space and many genes in the genom occupy preferred areas. The organization of chromosomal domains are associated to gene density and size. In this case, it has been reported that gene-rich chromosomes prefer interior positions and that gene-poor chromosomes prefer peripheral positions. Chromosomal domains are also dynamic structures, so genes can be displaced from the periphery to the interior position when opened. It is known that the spatial organization of the human genome plays an important role in the transcriptional control of genes. Based on studies of promoter and enhancer interactions by DNA looping, it is clear that gene expression is facilitated and regulated through contacts of distal chromatin contacts. The primary research topics are how regulatory DNA elements and genes are wired to properly execute cell-specific transcription regulatory programs. Genetic experiments have uncovered three rules of enhancer-promoter engagement: linear proximity matters, enhancer and promoter compatibility and some sequences exist that can block enhancer activity. To understand the molecular mechanisms behind these rules, we need to know how regulatory sites exert activities over distance. It is found that a given mammalian cell type contains thousands or more regulatory sites. With 200 different cell types, this confirms that our genome harbours a complex regulatory landscape. From linear DNA to the three dimensional nucleus, chromatin organization is well characterized on both the small scale and the very large scale; however, our understanding of the intermediate levels of chromatin organization remains limited. With the advent of chromosome conformation capture (3C) technologies tremendous progress in our understanding of three dimensional chromatin organization of interphase nucleus has been made. In this review, it is mentioned about spatial organization of genom, some interactions in this organisation and some actual studies in recent years.
\end{abstract}

KEYWORDS: Three dimensional genome, Chromosome territories, Enhancer, Insulator, Topological domains 


\section{GíRiş}

\section{Genom Topolojisi}

İnsan genomunun mekansal organizasyonunun genlerin transkripsiyonel kontrolünde önemli bir rol oynadığı bilinmektedir (1). Doğrusal DNA'dan üç boyutlu nükleusa kadar kromatin organizasyonu küçük ve büyük ölçekte çok iyi karakterize edilmiş olmakla birlikte, ara seviyelerdeki kromatin organizasyonu hakkındaki bilgilerimiz hala sınırlıdır. En iyi ölçekte, DNA ilk önce nükleozomlarda paketlenmekte ve kromatinin alt birimi olarak tanımlanmaktadır. Ökaryotik nükleozomun yapısı genel olarak korunmuştur: 147 baz çifti uzunluğunda DNA her biri iki kopyadan oluşan $\mathrm{H} 2 \mathrm{~A}, \mathrm{H} 2 \mathrm{~B}, \mathrm{H} 3$, ve $\mathrm{H} 4$ histon proteinlerinin etrafına sarılarak bir oktameri oluşturur (2). Beşinci histon olan $\mathrm{H} 1$ her nükleozomun sonunda bulunan nükleozomlar arası bağlaç bölgedeki DNA'ya bağlanır. Uzun nükleozom zincirleri sekonder helikal kromatin yapısını oluşturmak için daha da sıkılaşır. Bu silindirik solenoid iplik kromatin organizasyonunun temel birimi olarak görünmektedir. Solenoidler, $100 \mathrm{~kb}$ aralıklarla non-histon protein olan iskelet proteinine (scaffhold) veya matrikse bağlanarak ilmek veya bölgeler (domain) halinde paketlenir (3). DNA ilmeklerinin varlığı 1980'li yıllarda ilk kez prokaryotlardaki operonlar ve faj çalışmaları sayesinde tanımlanmıştır (4). Bu ilk çalışmalar DNA ilmeklenmesinin transkripsiyonda, replikasyonda ve rekombinasyonda rol oynadığını göstermiştir. Bununla birlikte DNA paketlenmesi ve kromozom yapısının, genom etkileşim özellikleri ve gen ekspresyonunun düzenlenmesini de kapsayan çok geniş bir yelpazede fonksiyonel rolleri olduğu kesinleşmiştir $(5,6)$. Kromatinin üç boyutlu yapısı oldukça dinamiktir ve hücre bölünmesi, hücresel farklılaşma, yaşlanma, hücre yazgısının yeniden programlanması ve kanser gelişimi gibi birçok süreçle ilişkilidir. Son zamanlarda, kromozom konformasyon yakalama teknolojilerini (3C: Chromosome Conformation Capture) kullanarak, genom mimarisinin dinamikleri, ilişkili proteinler ve kromatinin mekânsal organizasyonuna katılan mekanizmalar ve gen ekspresyonu ile ilgili birçok bulgu rapor edilmiştir (7). Genel olarak kromatinin paketlenme seviyesinin, gen ekspresyonunu engelleyen veya izin veren ortamı sağladığı kabul edilir (8). Bununla birlikte, bu durum gerçekten gen aktivitesi için belirleyici değildir. Gen aktivitesi, kromozomun topolojik birimlerini birleştiren veya etkileyen çoklu faktörler tarafından düzenlenen süreçlerin bir sonucudur. Gerçekte, aynı kromatin durumundaki tüm genlerin transkripsiyon oranı asla aynı değildir (9).

\section{Kromozom Alanları}

Genomların temel hücresel biyolojik birimi kromozomdur. 1980'lerde yapılan FISH deneyleri memeli hücrelerinde her bir kromozomun genetik materyalinin nükleusta mekânsal olarak sınırlı bölgeleri işgal ettiğini ve tipik olarak kabaca küresel bir şekilde 2-4 $\mu \mathrm{m}$ çapında olduğunu göstermiştir (10). Bu çalışmalar genomun nükleusun üç boyutlu yapısında birkaç hiyerarşik seviyede mekânsal olarak düzenlenmekte olduğuna dikkat çekmektedir. Hücre biyolojisinde "kromozom alanları" (chromosome territories) terimi nükleusun belli bölgelerinin belli kromozomlar tarafından kullanılmasını ifade etmektedir (Şekil 1).

Şekil 1: Kromozom alanları. (71, 72)'den değiştirilerek. TAD: Topological Associated Domains (Topolojik olarak ilişkili domainler).

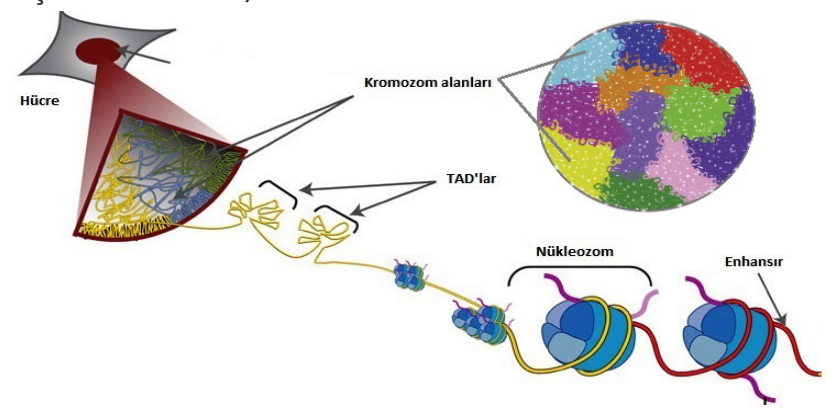

Bir başka deyişle, kromozomların nükleusta rastgele düzenlenmediği, genom içindeki bazı genlerin diğer bölgelere kıyasla tercihli bölgeleri işgal ettikleri veya nüklear zar, heterokromatin domainler veya nüklear cisimcik gibi nüklear yapıları seçtikleri farkedilmiştir (10-12). Her bir kromozomun mekânsal olarak belli alanlarda bulunuyor olmasışu soruyu akla getirmektedir:hangi kromozomlar ve dolayısıyla taşıdıkları genler üç boyutlu nükleus içinde rastgele düzenlenmekte veya tercihli bölgeleri işgal etmektedir? (11).

\section{Kompartımanlaşma}

Metafaz esnasında kromatin yüksek seviyede yoğunlaşır ve ışık mikroskobunda görünür hale 
gelir. Metafaz kromozomlarının morfolojileri çok iyi tanımlanmış olup şekil ve boyları ile karakterizedir. Buna zit olarak interfaz kromozomları oldukça gevşek formdadır ve ışık mikroskobu ile ayırt edilememektedir. Ancak yüksek çözünürlükteki mikroskoplarla yapılan çalışmalarda subdomainler içeren kromatin organizasyonunun varlığı ortaya konmuştur (Şekil 2) (13).

Şekil 2: Kromatin ilmeğinde domain ve sınırlar. (73)'den değiştirilerek.

TAD: Topological Associated Domains (Topolojik olarak ilişkili domainler). CTCF: CCCTC-binding factor.

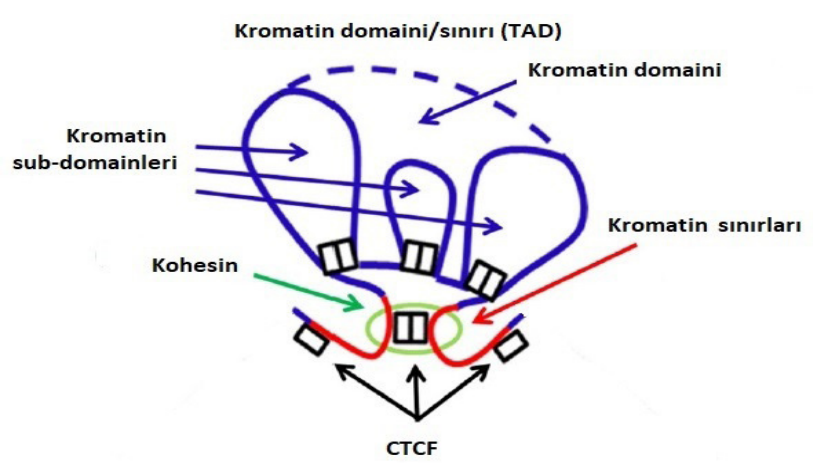

3C teknolojilerinin gelişmesi interfaz nükleusunun üç boyutlu kromatin organizasyonuna yeni bakış açısı getirmiştir. $3 C$ teknolojisi lokuslardaki düzenlemelerin çözülmesi için geliştirilmiştir. Bu teknoloji; mekânsal olarak proksimaldeki DNA dizilerinin çapraz bağlanması ve ligasyonuna dayanır, bunlar daha sonra PCR stratejileri ile tanımlanır ve sayısallaştırılır (14).

Tüm lokus çiftlerini de tek seferde sorgulamak için DNA yakınlık ligasyonu tekniği ile genom boyu yüksek verimli sekanslamayı birleştiren Hi-C tekniği geliştirilmiştir (15). Genomun üç boyutlu mimarisinin tespit edilmesinde kullanılan bu Hi-C teknolojisiyle (16) üretilmiş mekânsal yakınlık haritaları birçok domainin A ve B alt kromozomal kompartımana sahip olduğunu göstermiştir. Kompartıman A açık, ulaşılabilir, aktif olarak transkribe edilen kromatindir. B kompartımanı genom çölü olarak adlandırılmakta ve kapalı kromatini ifade etmektedir $(15,17,18)$. Nükleus içinde kromozomların düzenlenme modelinde A kompartımanındaki DNA'nın, iç kısımda halka şeklinde organize olduğu, B kompartımanındaki DNA'nın ise tercihen lamina ve çekirdekçiğin uç kısmıyla ilişkili olduğu belirtilmiştir (19) (Şekil 3). Genomun bu şekilde düzenlenmesi evrimsel olarak korunmuş olup, hem hücre tipi hem de doku tipine spesifiktir (20). Kromozom alanlarının dairesel organizasyonu gen yoğunluğu ve boyutu ile ilişkilidir.

Şekil 3: Kompartıman A/B sembolik yerleşimi. (7)'den değiştirilerek.
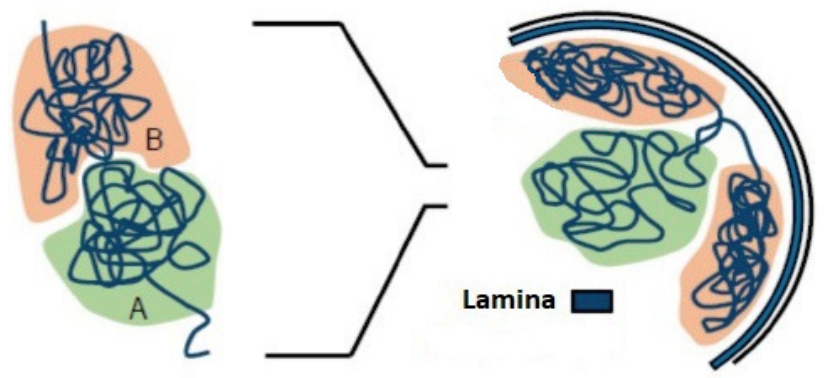

Bu durumda gen bakımından zengin kromozomların interior pozisyonları, gen bakımından zayıf kromozomların perifer pozisyonları tercih ettiği rapor edilmiştir (21-23). Kromozom alanları ayrıca dinamik yapılar olduğu için genler açılacağı zaman periferden interior pozisyona doğru yer değiştirebilirler (24). Tersi durumda genler zit yönde hareket edebilirler veya pozisyonlarını koruyabilirler $(25,26)$. Genlerin bulundukları kromozom alanlarından interkromatin kompartımana doğru veya komşu kromozom alanına doğru mekan değiştirmesine genellikle çözülmeye başlamış kromatin ilmekleri eşlik eder (20). Orsztynowicz ve ark. (27) beyin hücrelerinde yaptıkları kromatin çalışmalarında düzensiz şekli olan kromozom alanlarının artmış transkripsiyon aktivitesine eğilimli olduğunu bulmuşlardır. Transkripsiyon aktivitesi ve kromozom alanının şekli arasındaki ilişkiyi açıklayan bir diğer örnek X kromozomu inaktivasyonudur. Aktif ve inaktif $X$ kromozomu arasındaki karşılaştırmalar, inaktif kopyanın pürüzsüz ve yuvarlak bir yüzeye sahipken, aktif kopyasının daha düzensiz bir yüzeye sahip olduğunu göstermiştir (28). Bu çalışmalar kromozomların farkIı hücrelerde farklı konformasyonlara sahip olduğunu ve aktif kromatin olan A kompartımanı ile inaktif olan B kompartımanının hem kromozom içinde hem de global olarak nükleus içinde mekansal olarak ayrıldığını göstermektedir. Önemli olarak A/B kompartıman organizasyonu sadece interfaz hücrelerinde gözlenir. Mitoz esnasında kromatin yapısı yeniden düzenlenir $(18,29,30)$. Senkronize hücrelerde yapılan Hi-C 
çalışmaları profaza girdikten dakikalar sonra kromozomların A/B kompartıman özelliklerini kaybettiğini ortaya koymuştur. Bu durum şu soruyu akıllara getirmektedir: Kompartıman yapısı sonra nasıl yeniden düzenlenmektedir? (31).

\section{Yakınlık Durumu}

İnsan kromozomları ele alındığında bir kromozom üzerindeki herhangi iki bölgenin birbirleriyle temas etme olasılığı, farklı bir kromozom üzerindeki başka bir bölgeyle temas etme olasılığından daha yüksektir (15). Hi-C tekniği ile ilişkili genom konformasyon yakalama tekniği kullanılarak Drosophila melanogaster'in genom haritalanmasının sistematik analizleri yapılmıştır. Buna göre, baskılanmış domainlerin çoğunlukla aynı kromozom kolu üzerindeki diğer inaktif domainlerle etkileşim halinde olduğu, aktif domainlerin ise hem aynı kromozom kolu, hem farklı kromozom kolu hem de farklı kromozomlar üzerindeki aktif domainlerle etkileşim halinde olduğu rapor edilmiştir (31). Bu gözlemler, inaktif alanların, kromozomun iç kısmını veya iskeletini oluşturabildiğini gösterirken, aktif alanların, aynı veya farklı kromozomlar üzerindeki diğer aktif bölgelere temas etmek için bölgeden dışarı uzanabileceğini göstermektedir (5).

\section{Genomdaki Regülatör DNA Bölgeleri}

Genetik çalışmalar enhansır promotör birlikteliğinin üç kuralı etrafında tamamlanır: Doğrusal yakınlık durumları, enhansır promotör uyumu ve enhansır aktivitesini bloklayabilen sekansların varlığı. Bu kuralların arkasında yatan moleküler mekanizmaları anlamak için regülatör bölgelerin uzak mesafelerde nasıl faaliyet gösterdiğini bilmeye ihtiyacımız vardır (32). DNA molekülleri memeli nükleusu içinde sıkıca paketlenmektedir ve nükleozom ötesindeki kromatin organizasyonu hakkında az şey bilinmektedir. Kromozom katlanma prensiplerinin karmaşıklığı ve transkripsiyonel regülasyonu nasıl şekillendirdiği hakkında yapılan çalışmalarla yeni bilgilere ulaşılmaktadır. İlerleyen teknolojik gelişmeler, ilmekler halinde kromatin katlanmasının farklı kromozomlar üzerindeki lokusları bir araya getirdiğini ortaya çıkarmış- tır. Bu incelemeler genlerin diğer kromozomlar üzerindeki regülatör elemanlarla trans halinde düzenlenebileceği hipotezinin ortaya atılmasına neden olmuştur (33). Nitekim genlerin, promotörlerin, enhansırların, diğer fonksiyonel bölgelerin lokalizasyonları ile ekspresyon seviyeleri arasında ilişki olduğu bilinmektedir (34-37).

Genom içindeki regülatör DNA sekansları çeşitli metodlarla belirlenebilir. Geleneksel olarak in vitro tanımlama analizleri yapılmakta ve raportör bir gen taşıyan plazmide izole edilen sekans elemanı yerleştirilmektedir. Hücre içine transfekte edildikten sonra transkripsiyonu aktive etmekte, baskılamakta veya bir aktivatör ve gen promotörü arasına yerleştiğinde transkripsiyonel aktivasyonu nötralize etmektedir. Buna göre regülatör DNA sekansları enhansır veya izolatör vs. olarak sınıflandırılmaktadır. Yapılan çalışmalarda herhangi bir hücre tipinin binlerce ya da daha fazla regülatör DNA sekans bölgeleri içerdiği belirlenmiştir. 200 hücre tipi göz önüne alındığında insan genomunun karmaşık bir düzenleyici ortam olarak çalıştığı görülmektedir (32).

\section{Karmaşık Düzenleyici Ortam}

Düzenleyici ortam kavramı ilk defa Hox lokuslarının etrafındaki düzenleyici sekansların kompleks organizasyonunu tanımlamak için ortaya atılmıştır (38). Genomda bir gen doğru zaman ve doğru yerde nasıl eksprese olmaktadır? İnsan vücudunda aynı genoma sahip, her biri farklı morfoloji ve fonksiyonda olan 200'ün üzerinde farklı hücre tipi bulunmakta ve bu farklılıklar hücreye spesifik gen düzenleyici programlarla yönlendirilmektedir. Bu programların düzgün çalışması sadece protein kodlayan genlere değil, genler içindeki ve etrafındaki kodlanmayan sekanslara da bağlıdır. Transkripsiyonel kontrolü anlamak için genomun kodlanmayan kısmına yoğunlaşan çalışmalar, promotör ve enhansır arasındaki ilişkinin dikkate alınması gerektiğini ortaya koymaktadır. Şimdiye kadar bu çalışmalarda küme içindeki her bir özgün genin transkripsiyonunu zaman ve mekanda nasıl koordine ettiğini anlamak için Hox ve globin lokuslarıgibi gen kümelerine yoğunlaşılmıştır (32). 
DNA ilmeklenmesiyle promotör ve enhansır etkileşimleri temelli çalışmalar gen ekspresyonunun uzaktaki kromatin temaslarıla düzenlendiğini göstermiştir (39).

Transkripsiyon için doğrudan fonksiyonel sonuçları olan dört tip ilmek mevcuttur (40): Birinci tip, transkripsiyon sonlandırma bölgesiyle transkribe edilen genlerin $5^{\prime}$ ucuna katılır. Bu tip ilmekler RNA Pol II'nin terminasyon sonlanma bölgesinden tekrar promotöre dönmesine izin vermektedir. Böyle $5^{\prime}$ ucu ilmeklerinin varlığı kısa süreli represyondan sonra gen transkripsiyonunun hızlı şekilde aktive olma yeteneğiyle ilişkilidir (41). Bir diğer fonksiyonu ise protein kodlayan genlerin transkripsiyonunu doğrudan arttırmasıdır (Şekil 4a) (42). Düzenleyici ilmeklerin ikinci tipi, uzak bir noktadaki enhansırı promotörle temas haline getirmektedir. $\beta$-globin lokus kontrol bölgesi (LCR: Locus Control Region) bu tip ilmeklerin birçok örneğinin ilkidir (Şekil 4b) (43). İlmekli transkripsiyonel regülasyonun üçüncü tipi, distaldeki gen promotörlerine ulaşmak için polycomb cevap elementleri içeren bölgelerin katlanması yoluyla polycomb bağımlı represyondur. Polycomb-aracılı katlanmanın net sonucu aktivasyon yerine gen sessizleşmesi olsa da katlanma etkileşimlerine rehberlik eden moleküler mekanizmalar temel olarak farklı değildir (Şekil 4c) (44). Dördüncü tip ilmek etkileşimi CCCTC-bağlayıcı faktör (CTCF: CCCTC-binding factor) ve kohesin gibi izolatör bağlayıcı proteinleri içermektedir. İzolatörler, promotör ve enhansır arasına yerleştiklerinde de enhansırların promotörü aktive etmesini engelleyen kritik elementler olarak tanımlanmaktadır (Şekil 4d) (45).

Şekil 4: Transkripsiyon düzenleyici ilmeklerin dört tipi. (5)'den değiştirilerek.

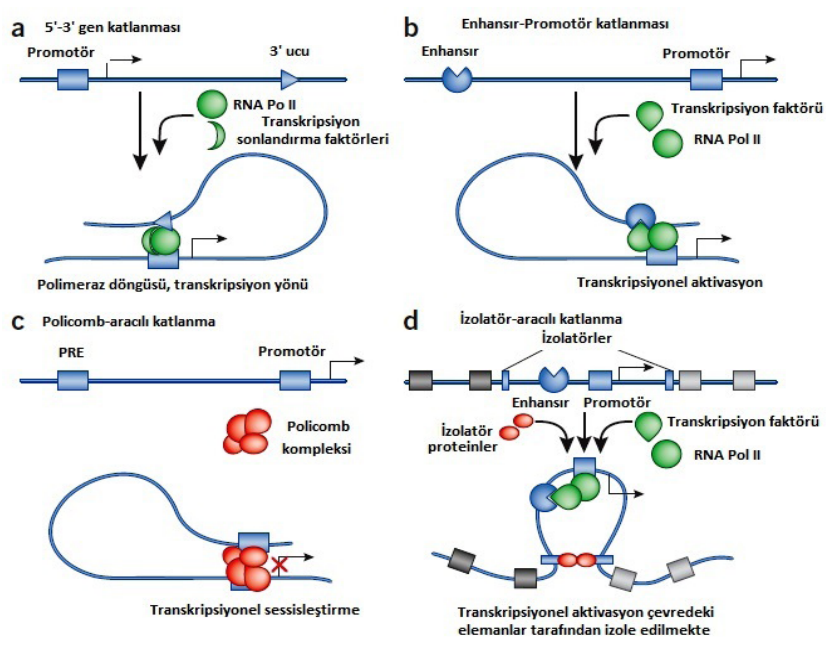

Genellikle enhansırların cis durumunda en yakın gen üzerinde etkili olduğu varsayılmaktadır ve çoğu durumda bu doğrudur. Lineer DNA dalı üzerindeki yakınlık veya genomik sıra, şeçicilik için temel belirleyicidir (Şekil 5I). Plazmid temelli rekabet analizlerinde ortak enhansırla aktive edilen proksimal genlerin distalde bulunan genlere göre avantajlı olduğu gösterilmiştir (46). Kromozomal durumda da transkripsiyonel regülasyon aynı kuralla işlemektedir (47). Regülatör bölgeye doğrusal yakınlık her ne kadar iyi belirleyici olsa da bazı durumlarda enhansırın yakınındaki geni atlayıp özellikle daha uzaktaki gen için aktive olduğu durumlar mevcuttur (48). Örneğin erken embriyonun desenlenmesinde önemli olan Sonic Hedgehog geninin $(\mathrm{SHH})$ enhansırı $1 \mathrm{Mb}$ uzaklıktadır. Neden enhansırlar daima yakındaki genin aktivasyonu için değil de bazen tercihli olarak daha uzaktaki genlerin aktivasyonunda çalışmaktadır? (32). Örneğin bazen bir enhansır aktif olduğu bir dokuda promotöre ulaşabilir olmamasından dolayı geni atlayabilir. $\beta$-globin lokusunda, LCR'ler sadece $\beta$-globin genleri üzerinde etki eder ve potansiyel olarak izolatör bölgeler bozulsa bile tamamen yakınındaki koku reseptör genlerini atlar (49). LCR ayrıca gelişimin daha sonraki basamaklarında daha uzaktaki yetişkin $\beta$-globin genleri üzerinde tam olarak etki etmek için yakınındaki fetal globin genlerini atlar. Belki de inaktivite veya promotöre ulaşılamaz olması, düzenleyici bölgelerin yakınındaki genleri atlaması için bir sebep olabilir (Şekil 5II). (32). Regülatör sisteminin varsayılan hedef genden daha fazla geni tesadüfen aktive ettiği düşünülebilir. Örneğin B-hücresine spesifik insan immünoglobulin beta geni $(\lg \beta)$ veya $C D 79 b$ yüksek seviyede eksprese edilmektedir, fakat muhtemelen fonksiyonel değildir. Hipofiz dokusunda daha uzakta bulunan büyüme hormonu geni $(h G H)$ üzerinde etki eden LCR bölgesine doğrusal yakınlığından dolayı eksprese edildiği öne sürülmüştür (50). Benzer fenomen birçok housekeeping genin bulunduğu yoğun gene sahip kromozomal bölgeler için de ortaya atılm ıştır. Gen ekspresyon seviyelerinin belirlenmesi için lokus civarındaki 500kb'lik bölge analiz edilmiş ve $300 \mathrm{~kb}$ uzaklıkta bulunan gama-fosfatların transferini katalize eden Nucleoside Diphosphate Kinase geninin (NME4), a-globin 
genlerinin aktif olduğu kırmızı kan hücrelerinde upregüle olduğu (ekpresyonunun arttığı) rapor edilmiştir. a-globin regülatör bölgelerinin bundan sorumlu olduğu ve NME4 geninin bu enhasırlar için a-globin geniyle rekabet halinde olduğu rapor edilmiştir (51). Bu verilerin hepsi değerlendirildiğinde dokuya spesifik genlerin her zaman gerçek hedef genlerin transkripsiyonunu aktive etmediği, yakınında bulunan fakat ilişkili olmadığı genlerin de transkripsiyonunu aktive ettiği ortaya konmuştur.

Şekil 5: Enhansır-Promotör etkileşim örnekleri. (32)'den değiştirilerek. E: Enhansır. CTCF: CCCTC-binding factor (izolatör).

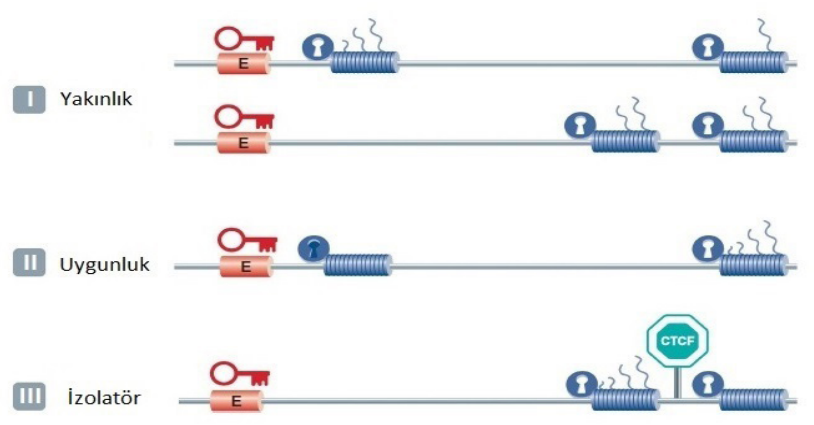

\section{Topolojik Olarak iliş̧kili Domainler}

Hi-C tekniği ile yapılan analizlerle küçük domainlerin varlığı öne sürülmüş ve kompartımanların yaklaşık bir megabaz uzunluğunda kondanse yapılara bölündüğü varsayımına neden olmuştur. Bu yapılar "topolojik olarak ilişkili domainler (TADs: Topological Associated Domains)" veya "topolojik domainler" olarak isimlendirilmiştir $(52,53)$. Prensipte $\mathrm{Hi}-\mathrm{C}$ tüm genom boyunca ilmekleri tespit etmek için kullanılabilir. Bununla birlikte, bunu başarmak için, çok büyük veri setleri ve titiz hesaplama yöntemleri gereklidir. İlaveten, yüksek çözünürlüklü $\mathrm{Hi}-\mathrm{C}$ analizleri TAD'lar içinde alt TAD yapılarının (veya kromatin ilmeklerinin) olduğunu ortaya koymuştur $(54,55)$ (Şekil 2). TAD yapıları mitozda kaybolur ancak G1 fazında yeniden oluşur (18). TAD'lar hücre çeşitleri ve türler arasında oldukça kararlı yapıda olduklarından fonksiyonel öneme sahiptir. Genomun TAD'lara ayrılması enhansırların hedef promotörleriyle nasıl etkileşim haline geldiğinin anlaşılmasını sağlayabilir. Kromatin etkileşimlerinin TAD'larla sınırlandırılabileceği rapor edilmiştir (56). Aynı TAD içindeki genler transkripsiyonel olarak koreledir (57). TAD sınırlarının ortadan kalkması gen ekspresyon paternlerini değiştirmektedir (53).

\section{İolatörler}

İzolatör elemanların keşfine ilk yol açan fikir genomun her biri bağımsız regülatör aktiviteye sahip fiziksel olarak ayrılmış kromatin domainlerine ayrılmış olması fikridir. Bu nedenle bu domainler arasında düzenleyici etkileşimi engelleyen sınırların olması gerekmektedir. Bu hipotezi test etmek için yapılan analizlerde "izolatörler" olarak tanımlanan yeni bir düzenleyici sınıf tanımlanmıştır. Memelilerde özellikle CCCTC-bağlayıc faktör (CTCF: CCCTC-binding factor) olarak isimlendirilen proteinin izolatör aktivitesi ile ilişkili olduğu gösterilmiştir (58). CTCF bölgelerinin mekânsal olarak ayrılan kromatin domain sınırlarında lokalize olduğu ve bu izolatör sekansların kromozom topolojisini güçlü şekilde etkilediği öne sürülmektedir (59) (Şekil 2). İn vitro raportör denemelerde CTCF DNA'ya bağlanmakta ve bir enhansır blokeri gibi çalışmaktadır (Şekil 5, III). İn vivoda CTCF bağlanma bölgeleri insan ve fare $\beta$-globin genleri ve $X$ kromozomu üzerinde $X$ inaktivasyonundan kaçan genler gibi aktif genlerin hemen yanında veya baskılanmış kromatin etrafında bulunabilirler (60). CTCF ayrıca H19-lgF2 lokusunda imprintlenmiş gen ekspresyonuna aracılık etmek için allele spesifik bir enhansır blokeri gibi işlev görmektedir (61). Genom boyu bağlanma bölgelerinin profilini elde etmek için yapılan çalışmalarda insan genomunda yaklaşık 20.00087.000 arasında CTCF bağlanma bölgesinin olduğu gösterilmiştir $(62,63)$. Bunun anlamı ortalama her 35-155 kb'de bir CTCF bağlanma bölgesinin varlığıdır. Kromozomal bölgelerin hücre nükleusunun periferi veya iç kısmında tercihi olarak lokalize olmasını sağlayan lamina ile ilişkili veya ilişkili olmayan domainler arasındaki sınırda yoğunlaşmış durumdadırlar (59). Dahası CTCF bölgeleri tarafından ayrılan genler gen ekspresyonları bakımından büyük ölçüde azalmış korelasyon göstermektedirler (64).

\section{Kohesinler}

CTCF genomik bağlanma bölgeleriyle kohesin arasında önemli çalışmalar mevcuttur $(65,66)$. Kohesin kompleksi mitoz esnasında kardeş kromatidlerin kohezyonunu sağlayarak mitoz esnasında önemli bir rol oynar. Bununla birlikte, DNA tamir mekanizması, homolog rekombinasyon ve en önemlisi de genomun cis-regülatör elemanları arasındaki uzun mesafeli 
etkileşimlere katılmaktadır. Kohesin kompleksi, SMC1, SMC3, RAD21 ve STAG1/STAG2'den oluşan bir evrimsel korunmuş multimerik protein kompleksidir (67). Kohesin bağlanma noktaları genom boyu CTCF bağlanma noktalarıyla katlanmaktadır (66). Bunların çoğu hücre tipi ve türü arasında korunmuştur (68). Bu durum da TAD sınırlarının hücre tipleri boyunca korunmasını potansiyel olarak açıklamaktadır (54).

\section{SONUÇ}

Makale boyunca bahsedildiği gibi, doğrusal DNA hem kendi içinde hem de bulunduğu mekanda belli bir mimariye sahiptir. Bu yapı ve organizasyon içindeki dinamikler, temaslar, katlanmalar, kompartımanlaşmalar vs. hücrenin doğru çalışması için gereklidir. Uluslararası İnsan Genom Sekanslama Konsorsiyumu (69) tarafından insan genomunun tamamen sekanslanması, genomun barındırdığı potansiyel için sadece kısmi bilgiler sağlamıştır. Kromatin etkileşimlerini belirlemek için geliştirilen yeni teknolojilerle dinamik genom organizasyonunun fonksiyonel önemi ve potansiyeli çalışılmaya devam edilmektedir.

Eagen (70), kromozom mimarisinin kuralları ile ilgili makalesinde halen cevaplanması gereken bazı sorulara dikkat çekmiştir. Örneğin; TAD'lar içinde domainler arası temasların fiziksel doğası nedir? TAD sınırları nasıl oluşturulmaktadır? Genomik aralıkları farklı kompartımanlar ve sub-kompartımanlara ayıran biyokimyasal kuvvetler nelerdir? CTCF'nin ilmekleri stabilize etmek için hangi moleküler etkileşimlere intiyaç vardır? IIlmekler ve kompartımanlaşma biyolojik fonksiyonu nasıl etkilemektedir? Bu konuyla ilgili cevaplanacak birçok soru mevcuttur. Soruların cevapları ve potansiyelin büyüklüğü, ancak genomun tamamen deşifre edilmesiyle anlaşılacaktır.

\section{KAYNAKLAR}

1. Bickmore W. The spatial organization of the human genome. Annual review of genomics and human genetics. 2013;(14):67-84.

2. Luger $K$, Mäder AW, Richmond, RK, Sargent DF, Richmond TJ. Crystal structure of the nucleosome core particle at 2.8 Å resolution. Nature 1997;(389):251-260.

3. Robert L. Nussbaum, Roderick R Mclnnes, Huntington F Willard, Thomson-Thompson Tıbbi Genetik Kitabı 2005, Güneş Kitabevi, Ankara
4. Schleif R. DNA looping. Annual review of biochemistry. 1992;(61):199-223.

5. Cavalli G, Misteli T. Functional implications of genome topology. Nat Struct and Mol Biol 2013; (20):290-299.

6. Feng S, Cokus SJ, Schubert V, Zhai J, Pellegrini $M$, Jacobsen SE. Genome-wide $\mathrm{Hi}-\mathrm{C}$ analyses in wildtype and mutants reveal high-resolution chromatin interactions in Arabidopsis. Mol Cell 2014;(55):694-707.

7. Sun L, Yu R and Dang W. Chromatin Architectural Changes during Cellular Senescence and Aging. Genes 2018;(9):211; Doi:10.3390/genes9040211

8. Kharchenko PV, Alekseyenko AA, Schwartz YB, et al. Comprehensive analysis of the chromatin landscape in Drosophila melanogaster. Nature 2011;(471):480-485.

9. Gierman HJ, Indemans MHG, Koster J et al. Domainwide regulation of gene expression in the human genome. Genome Res 2007;(17):1286-1295.

10. Lanctot C, Cheutin T, Cremer M, Cavalli G, Cremer T. Dynamic genome architecture in the nuclear space: regulation of gene expression in three dimensions. Nat Rev Genet 2007;(8):104-115.

11. Misteli T. Beyond the sequence: Cellular organization of genome function. Cell 2007;(128):787-800.

12. Rajapakse I, Groudine M. On emerging nuclear order. J Cell Biol 2011;(192):711-721.

13. Cremer T, Cremer M. Chromosomal territories. Cold Spring Harb Perspect Biol 2010;(2):a003889. doi:10.1101/ cshperspect.a003889

14. Dekker J, Rippe K, Dekker M, Kleckner N. Capturing chromosome conformation. Science 2002;(295):13061311

15. Lieberman-Aiden $E$, van Berkum NL, Williams $L$, et al. Comprehensive mapping of long-range interactions reveals folding principles of the human genome. Science 2009;(326):289-293.

16. Van Berkum NL, Lieberman-Aiden E, Williams $L$, et al. Hi-C: a method to study the three-dimensional architecture of genomes. J Vis Exp 2010;May 6;(39). pii: 1869. doi: $10.3791 / 1869$.

17. Dekker J, Marti-Renom MA, Mirny LA. Exploring the three-dimensional organization of genomes: interpreting chromatin interaction data. Nat Rev Genet 2013;(14):390-403.

18. Naumova N, Imakaev $M$, Fudenberg $G$, et al. Organization of the mitotic chromosome. Science 2013;(342):948-953.

19. Serizay J, Ahringer J. Genome organization at different scales: nature, formation and function. Curr Opin Cell Biol 2018;(52):145-153.

20. Meaburn KJ, Misteli T. Cell biology: chromosome territories. Nature 2007; 445(7126):379-781. 
21. Mayer R, Brero A, von Hase J, Schroeder T, Cremer T, Dietzel S. Common themes and cell type specific variations of higher order chromatin arrangements in the mouse. BMC Cell Biol. 2005;(6):44.

22. Tanabe $H$, Habermann FA, Solovei I, Cremer $M$, Cremer T. Non-random radial arrangements of interphase chromosome territories: evolutionary considerations and functional implications. Mutat Res 2002; 504(1-2):37-45.

23. Sun HB, Shen J, Yokota H. Size-dependent positioning of human chromosomes in interphase nuclei. Biophys J 2000; 79(1):184-90.

24. Chuang $C$, Carpenter $A E$, Fuchsova $B$, Johnson $T$, de Lanerolle $\mathrm{P}$, Belmont AS. Long-range directional movement of an interphase chromosome site. Curr Biol 2006; 16(8):825-31.

25. Galiová G, Bártová E, and Kozubek S. Nuclear topography of beta-like globin gene cluster in IL-3stimulated human leukemic K-562 cells. Blood Cells Mol Dis 2006;33(1):4-14.

26. Foster HA, Bridger JM. The genome and the nucleus: a marriage made by evolution. Genome organisation and nuclear architecture. Chromosoma 2005;114(4):212-29.

27. Orsztynowicz M, Lechniak D, Pawlak P, et al. Changes in chromosome territory position within the nucleus reflect alternations in gene expression related to embryonic lineage specification. PLoS ONE 2017;(12)e0182398. [

28. Eils $R$, Dietzel $S$, Bertin E, Schrock E. Threedimensional reconstruction of painted human interphase chromosomes: Active and inactive $X$ chromosome territories have similar volumes but differ in shape and surface structure. J Cell Biol 1996;(135):1427-1440.

29. Croft JA, Bridger JM, Boyle S, Perry P, Teague $P$, Bickmore WA. Differences in the localization and morphology of chromosomes in the human nucleus. J Cell Biol 1999;(145):1119- 1131.

30. Gibcus JH, Samejima K, Goloborodko A, et al. A pathway for mitotic chromosome formation. Science 2018:6135.

31.SextonT, Yaffe E, Kenigsberg Eet al.Three-dimensional folding and functional organization principles of the Drosophila genome. Cell 2012;(148):458-472.

32. Splinter $\mathrm{E}$, de Laat $\mathrm{W}$. The complex transcription regulatory landscape of our genome: control in three dimensions. EMBO J 2011;(30):4345-4355.

33. Williams A, Spilianakis CG, Flavell RA. Interchromosomal association and gene regulation in trans. Trends Genet 2010;(26):188-197.

34. Yu H, Zhu S, Zhou B, Xue H, Han JD. Inferring causal relationships among different histone modifications and gene expression. Genome Res 2008;(18):1314-1324.
35. Bock C, Lengauer T. Computational epigenetics. Bioinformatics 2008;(24):1-10.

36. Roy S, Ernst J, Kharchenko PV, et al. Identification of functional elements and regulatory circuits by Drosophila modENCODE. Science 2010;(330):1787-1797.

37. Gerstein MB, Lu ZJ, Van Nostrand EL, et al. Integrative analysis of the Caenorhabditis elegans genome by the modENCODE project. Science 2010;(330): 1775-1787.

38. Spitz F, Gonzalez F, Duboule D. A global control region defines a chromosomal regulatory landscape containing the HoxD cluster. Cell 2003;(113): 405-417.

39. Denholtz M, Plath K. Pluripotency in 3D: Genome organization in pluripotent cells Curr Opin Cell Biol. 2012;December;24(6):793-801.

40. Hou C, Corces VG. Throwing transcription for a loop: expression of the genome in the 3D nucleus. Chromosoma 2012;(121):107-116.

41. Tan-Wong SM, Wijayatilake HD, Proudfoot NJ. Gene loops function to maintain transcriptional memory through interaction with the nuclear pore complex. Genes 2009;(23):2610-2624.

42. Tan-Wong SM, J B. Zaugg JB, Camblong J. et al. Gene loops enhance transcriptional directionality. Science 338, 671-675 (2012).

43. Tolhuis B, Palstra RJ, Splinter E, Grosveld F, de Laat, $W$. Looping and interaction between hypersensitive sites in the active beta-globin locus. Mol Cell 2002;(10):14531465.

44. Breiling A, Turner BM, Bianchi ME, Orlando V. General transcription factors bind promoters repressed by Polycomb group proteins. Nature 2001;(12):651-655 .

45. Yang J, Corces VG. Insulators, long-range interactions, and genome function. Curr Opin Genet Dev 2012;(22):8692.

46. De Villiers J, Olson L, Banerji J, Schaffner W. Analysis of the transcriptional enhancer effect. Cold Spring Harb Symp Quant Biol 1983;47(Part 2): 911-919.

47. Dillon N, Trimborn T, Strouboulis J, Fraser P, Grosveld F. The effect of distance on long-range chromatin interactions. Mol Cell 1997;(1):131-139.

48. De Laat W, Grosveld F. Spatial organization of gene expression: the active chromatin hub. Chromosome Res 2003;(11):447-459.

49. Splinter $\mathrm{E}$, Heath $\mathrm{H}$, Kooren J, et al. CTCF mediates longrange chromatin looping and local histone modification in the beta-globin locus. Genes Dev 2006;(20): 23492354. 
50. Cajiao I, Zhang A, Yoo EJ, Cooke NE, Liebhaber SA. Bystander gene activation by a locus control region. EMBO J 2004;(23):3854-3863.

51. Lower KM, Hughes JR, De Gobbi M, et al. Adventitious changes in long-range gene expression caused by polymorphic structural variation and promoter competition. Proc Natl Acad Sci USA 2006;(106):2177121776.

52. Dixon J, Selvaraj S, Yue F, et al. Topological domains in mammalian genomes identified by analysis of chromatin interactions. Nature 2012;(485):376-380.

53. Nora E, Lajoie B, Schulz E, et al. Spatial partitioning of the regulatory landscape of the $\mathrm{X}$-inactivation centre. Nature. 2012;(485):381-385.

54. Phillips-Cremins JE, Sauria ME,Sanyal A, et al. Architectural Protein Subclasses Shape 3D Organization of Genomes during Lineage Commitment Cell 2013;(153):1281-1295.

55. Rao SS, Huntley MH, Durand NC et al. A 3D Map of the Human Genome at Kilobase Resolution Reveals Principles of Chromatin Looping. Cell 2015;(162)3:687-688.

56. Jin F, Li Y, Dixon JR, et al. A high-resolution map of the three-dimensional chromatin interactome in human cells. Nature 2013;(503):290-294.

57. Flavahan WA, Drier $Y$, Liau BB, et al. Insulator dysfunction and oncogene activation in IDH mutant gliomas. Nature. 2015;529(7584):110-114.

58. Bell AC, West AG, Felsenfeld G. The protein CTCF is required for the enhancer blocking activity of vertebrate insulators. Cell 1999;(98):387-396.

59. Guelen L, Pagie L, Brasset E, et al. Domain organization of human chromosomes revealed by mapping of nuclear lamina interactions. Nature 2008;(453):948-951.

60. Filippova GN, Cheng MK, Moore JM, Tet al. Boundaries between chromosomal domains of $X$ inactivation and escape bind CTCF and lack CpG methylation during early development. Dev Cell 2005;(8):31-42.

61. Hark AT, Schoenherr CJ, Katz DJ, Ingram RS, Levorse JM, Tilghman SM. CTCF mediates methylation-sensitive enhancer-blocking activity at the H19/lgf2 locus. Nature 2000;(405):486-489.

62. Barski A, Cuddapah S, Cui K, et al. High-resolution profiling of histone methylations in the human genome. Cell 2007;(129):823-837.

63. Kunarso G, Chia NY, Jeyakani J, et al. Transposable elements have rewired the core regulatory network of human embryonic stem cells. Nat Genet 2010;(42): 631634.
64. Xie X, Mikkelsen TS, Gnirke A, Lindblad-Toh K, Kellis $M$, Lander ES. Systematic discovery of regulatory motifs in conserved regions of the human genome, including thousands of CTCF insulator sites. Proc Natl Acad Sci USA 2007;(104): 7145-7150.

65. Parelho V, Hadjur S, Spivakov M, et al. Cohesins functionally associate with CTCF on mammalian chromosome arms. Cell 2008;(132): 422-433.

66. Wendt KS, Yoshida K, Itoh T, et al. Cohesin mediates transcriptional insulation by CCCTC-binding factor. Nature 2008;(451):796-801.

67. Smith JS, Savage KI, Thompson A, Mills KI. Loss of Function Cohesin Complex Gene Mutations Create Neomorphic Cell States Advantageous to Oncogenesis Blood 2016;(128):1564-1565.

68. Schmidt D, Schwalie PC, Wilson MD, et al. Waves of retrotransposon expansion remodel genome organization and CTCF binding in multiple mammalian lineages. Cell. 2012;(148):335-348.

69. International Human Genome Sequencing Consortium. Finishing the euchromatic sequence of the human genome. Nature 2004;(431):931-945.

70. Eagen KP. Principles of Chromosome Architecture Revealed by Hi-C. Trends Biochem Sci 2018;(43)No.6: 469478.

71. Aranda S, Mas G, and Di Croce L. Regulation of gene transcription by Polycomb proteins Sci Adv 2015;(1):no. 11, e1500737. doi: 10.1126/sciadv.1500737.

72. Bodnar MS, Spector DL. Chromatin Meets Its Organizers. Cell 2013;153(6):1187-1189.

73. Bernardi G. Chromosome Architecture and Genome Organization. PLoS ONE. 2015;10(11):e0143739. doi: 10.1371 / journal.pone.0143739. 